DOI https://doi.org/10.18551/rjoas.2018-12.16

\title{
INFLUENCE OF GOVERNMENT POLICY, INDIVIDUAL CHARACTERISTICS, FAMILY AND TRAINING TOWARDS ENTREPRENEURIAL ORIENTATION AND ENTREPRENEURIAL ORIENTATION TOWARDS PERFORMANCE OF FEMALE ENTREPRENEUR IN JAKARTA
}

\author{
Mahmudah Siti* \\ IPWI Higher Institute of Economics, Jakarta, Indonesia \\ Priadana Sidik, Maqin Abdul \\ Pasundan University, Bandung, Indonesia \\ *E-mail: sitimahmudah@stieipwija.ac.id
}

\begin{abstract}
The role of female in entrepreneurship sector is increasing quite rapidly. Objective of this study is to describe how much influence government policy, individual characteristics, family and training towards entrepreneurial orientation and their impact towards performance of female entrepreneur. Based on the Structural Equation Model/SEM analysis, government policy, individual characteristics and training had significant influence towards entrepreneurial orientation, but family did not. Furthermore, entrepreneurial orientation had significant influence towards entrepreneurial performance.
\end{abstract}

\section{KEY WORDS}

Government policy, individual characteristics, family, training, entrepreneurial orientation, female entrepreneur performance.

As potential human capital, female plays significant role in national development. The percentage of female in Indonesia is $49.65 \%$, in which majority of female is within the productive age range. In 2012, out of 245.425 million people, 121.855 millions are female. Nearly $60 \%$ of these female are between 15 between 54 years old. In other words, about 70 million female is within the productive age range and able to give significant contribution to the national development. Indonesian population is approximately 250 million people and $60 \%$ of this population is female entrepreneur. Furthermore, in $2012,50.69 \%$ of the population in DKI Jakarta is male citizens while the remaining $49.31 \%$ is female (National Bureau of Statistics of Jakarta, 2012). Neither the National Buerau of Statistics nor that of DKI Jakarta, the capital city of Indonesia, had any data about number of female entrepreneurship in Indonesia. Asosiasi Pengusaha Wanita Indonesia (IWAPI), Alisa Khadijah ICMI (Ikatan Cendikia Muslim Indonesia) or Muslimat NU, three female entrepreneurship associations in Indonesia, did not have any national female entrepreneurship database either. Instead, they have information about their members, who mostly live in big cities in Indonesia.

Female entrepreneurs in one area can develop a community. Female has innate ability in communication and therefore can develop their business and networking more quickly. At the same time, female entrepreneurs are facing several obstacles, for example patriarchal culture that gives power and importance to men. In most Asian countries, female has to ask for their husband's blessing prior to starting a business (Inmyxai et al, 2010). Based on the explanation, the researchers are interested in conducting the study.

\section{LITERATURE REVIEW}

Role refers to an action. It is a verb that means function or activity. Based on the Indonesian Dictionary, role refers to a set of behavior that an individual is expected to have in society (Harahap, 2007). George J. Stigle as cited in Harefa (2008) explained that policy is a 
set of formal rule that aims to provide protection and benefit for society or community group. Titmuss as cited in Sugiharto (2012) defined policy as a set of principles that maintain an action in order to achieve particular objectives. Policy, according to Titmuss, has always been problem-oriented and action-oriented. Therefore, policy is a well-organized plan of action that consists of some principles to guide an action in order to achieve particular goals. Policy is closely associated to the government because government has authority and power to manage citizens and is responsible for public service. Siagian (2008) stated that biographically individual characteristics can be observed based on age, sex, marital status, number of dependence, working experience and background of education. Another indicator is psychological characteristics of an individual that explains why an individual is interested in becoming an entrepreneur. Psychological characteristics consist of need for achievement, self esteem and self-efficacy (Sirec \& Mocnik, 2010), personal characteristics such as motivation to start a business and cognitive aspect (Jung, et.al, 2001).

Syamsu Yusuf (2012) postulated that "environment is an entire physical/natural (event, situation or condition) or social phenomenon that influences and is influenced by individual development." Gunarsa as cited in Roy Manihai (2009) stated that family is "the first environment that has significant influence towards a child." A family is a major group that requires intimate individuals who have frequent face-to-face meeting between each other, share similar norms (expectation on how group members should behave), survival skills and extensive influence. Therefore, family member as part of a primary group has extreme influence towards each other. The second concept in family is "being responsible for each other." Family is an individual who is accustomed of trading sector because his or her family owns a business (Leon et al., 2007). This individual will observe his or her parents' business. As the result, the individual is interested in a type of occupation with high flexibility and independence (Brockhause, Hisrich \& Brush, as cited in Leon, et al., 2007).

Education and training have the same objectives, namely learning. Learning consists of gradual and continuous understanding. Brown (2004) stated that "education aims to provide knowledge while training aims to improve behavior." Based on this idea, training is supposed to be more organized than education because transfer of knowledge can happen anytime. Training should be developed in a systematic and schematic manner in order to achieve an estimated target. Entrepreneurial performance is a multidimensional concept and relationship between entrepreneurial orientation and performance may rely on several indicators used to access performance (Lumpkin \& Dess, 2001). Hoque and James (2000) identified five dimensions of performance, namely ROI (Return on Investment), sales margin, utilization capacity, customer satisfaction and product quality. Due to different perspective, there is not any standardized indicator to measure entrepreneurial performance. Entrepreneurial performance is measured based on various aspects and it is extensive in nature. Moores and Yuen (2001) evaluated entrepreneurial performance based on sales growth, operating cashflow, ROI/ ROA and net profit against sales.

\section{METHODS OF RESEARCH}

The study was categorized as an explanatory survey. The sampling technique was probability sampling, more particularly proportionate stratified sampling. The data analysis method was Structural Equation Model (SEM). The objective was to test the model and hypothesis The Structural Equation Model was carried out in two phases, namely Goodness of Fit and causal significance testing through regression coefficient test.

\section{RESULTS AND DISCUSSION}

Based on the statements of problems and structural equation model, there were two Structural Equation Model (SEM) analyses. The first Structural Equation Model aimed to answer "how much simultaneous and partial influence government policy, individual characteristics, family and training have towards entrepreneurial orientation of female entrepreneurs in DKI Jakarta." The second one aimed to answer "how much influence 
entrepreneurial orientation has towards entrepreneurial performance of female entrepreneurs in DKI Jakarta." Figure 1 showed result of analysis using Amos 21 for the first Structural Equation Model.

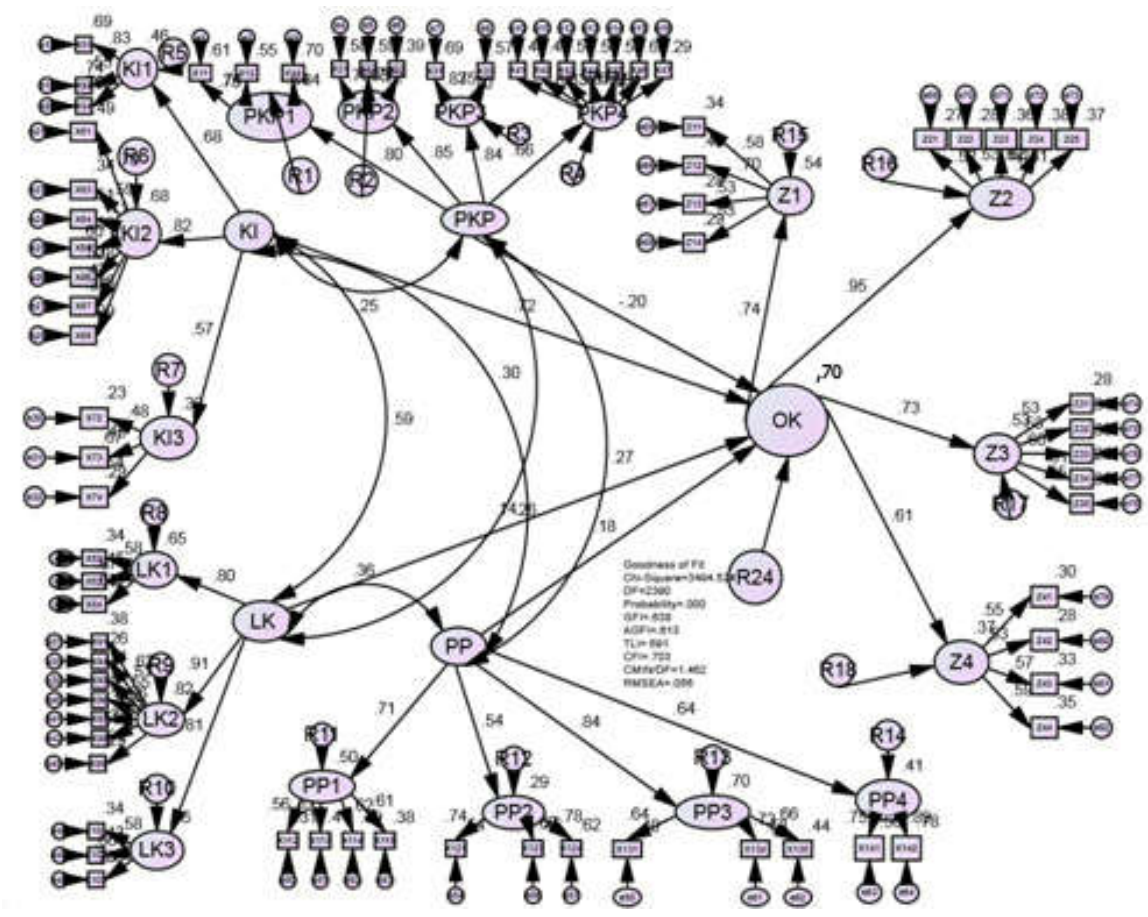

Figure 1 - The First Structural Equation Model

Table 1 showed Goodness of Fit Index of the First Structural Equation Model (SEM).

Table 1 - Goodness of Fit Index of the First Structural Equation Model (SEM)

\begin{tabular}{|c|c|c|c|c|}
\hline No & Goodness of fit index & Cut of Value & Result & Model Evaluation \\
\hline 1 & $X^{2}-$ Chi-Square & $<3348.024$ & 3494.524 & Marginal \\
\hline 2 & Probability & $\geq 0.05$ & 0.000 & Marginal \\
\hline 3 & GFI & $\geq 0.90$ & 0.638 & Marginal \\
\hline 4 & AGFI & $\geq 0.90$ & 0.613 & Marginal \\
\hline 5 & TLI & $\geq 0.95$ & 0.691 & Marginal \\
\hline 6 & CFI & $\geq 0.95$ & 0.703 & Good \\
\hline 7 & CMIN/DF & $\leq 2.00$ & 1.462 & Good \\
\hline 8 & RMSEA & $\leq 0.08$ & 0.056 & \\
\hline
\end{tabular}

Source: Primary Data, 2017.

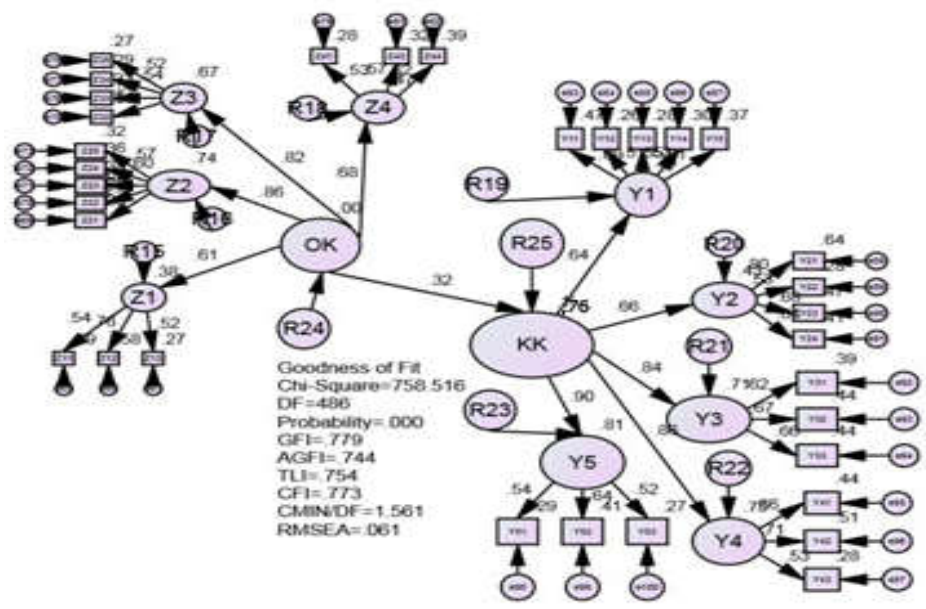

Figure 2 - The Second Structural Equation Model 
Table 1 showed the model met two criteria, namely CMIN/DF of $1.462<2.00$ and RMSEA of $0.056<0.08$. However, it did not meet other six criteria, namely chi-square $\left(X^{2}\right)$, p-value, GFI, AGFI, TLI, and CFI. Figure 2 showed result of analysis using Amos 21 for the second Structural Equation Model. (SEM).

Table 2 showed Goodness of Fit Index of the Second Structural Equation Model

Table 2 - Goodness of Fit Index of the Second Structural Equation Model (SEM)

\begin{tabular}{|c|c|c|c|c|}
\hline No & Goodness of fit index & Cut of Value & Result & Model Evaluation \\
\hline 1 & $\mathrm{X}^{2}-$ Chi-Square & $<3348.024$ & 758.516 & Marginal \\
\hline 2 & Probability & $\geq 0.05$ & 0.000 & Marginal \\
\hline 3 & GFI & $\geq 0.90$ & 0.779 & Marginal \\
\hline 4 & AGFI & $\geq 0.90$ & 0.744 & Marginal \\
\hline 5 & TLI & $\geq 0.95$ & 0.754 & Marginal \\
\hline 6 & CFI & $\geq 0.95$ & 0.773 & Good \\
\hline 7 & CMIN/DF & $\leq 2.00$ & 1.561 & Good \\
\hline 8 & RMSEA & $\leq 0.08$ & 0.061 & \\
\hline
\end{tabular}

Source: Primary Data, 2017.

Table 2 showed the model met two criteria, namely CMIN/DF of $1.561<2.00$ and RMSEA of $0.061<0.08$. However, it did not meet other six criteria, namely chi-square $\left(X^{2}\right)$, p-value, GFI, AGFI, TLI, and CFI. Figure 3 showed result of analysis using Amos 21 for Full Structural Equation Model.

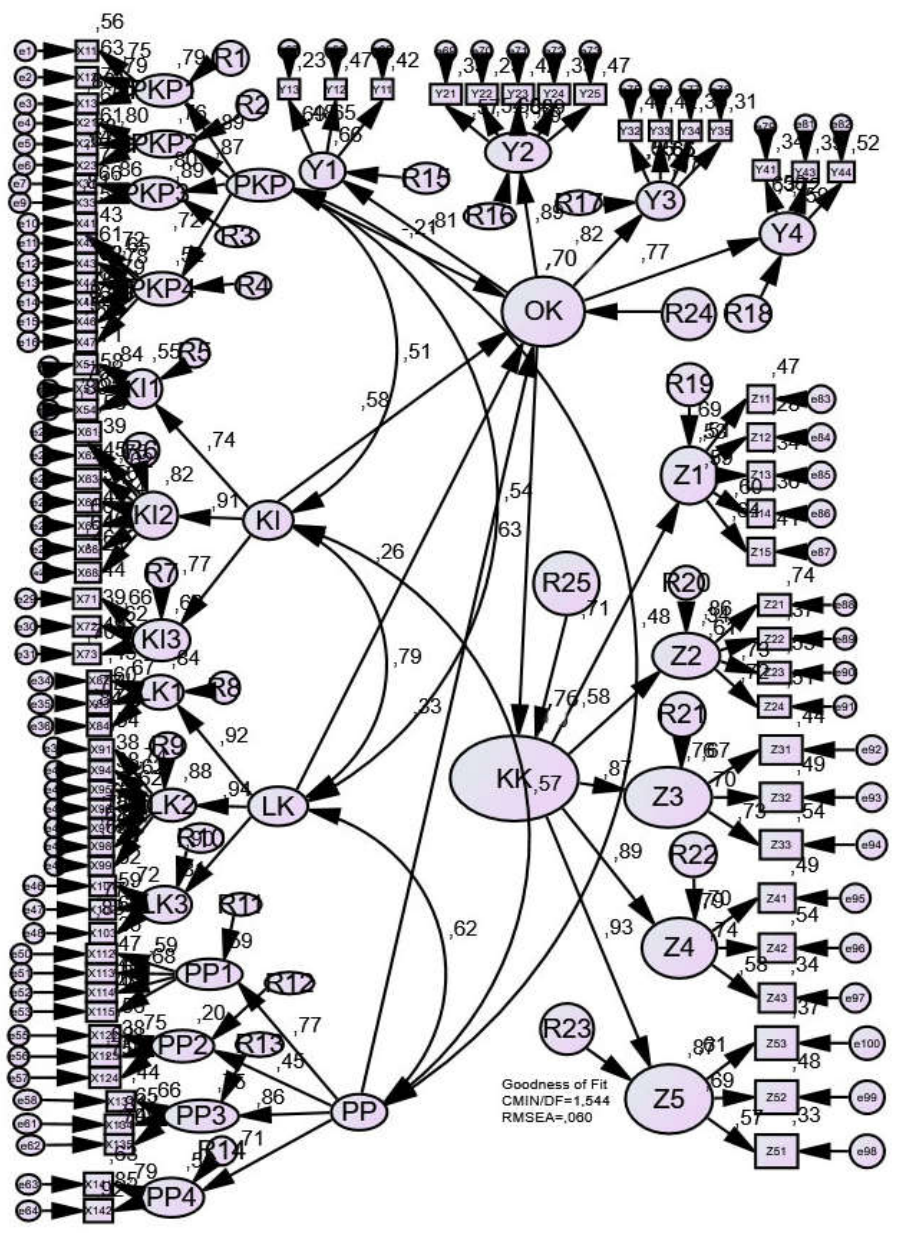

Figure 3 - Full SEM Model 
The causal significance test can be analyzed using t-test towards regression weight the full model resulted in. Table 3 showed result of the causal significance test of the model.

Table 3 - Causal Significance Test of the Structural Equation Model

\begin{tabular}{|c|c|c|c|c|c|c|c|}
\hline \multicolumn{3}{|c|}{$\mathrm{n} / \mathrm{n}$} & Estimate & S.E. & C.R. & P & Label \\
\hline OK & $<---$ & PKP & -0.141 & 0.062 & -2.277 & 0.023 & Significant \\
\hline OK & $<---$ & KI & 0.511 & 0.155 & 3.304 & 0.000 & Significant \\
\hline OK & $<---$ & LK & 0.110 & 0.081 & 1.367 & 0.172 & Non- Significant \\
\hline OK & $<---$ & PP & 0.376 & 0.171 & 2.199 & 0.028 & Significant \\
\hline KK & $<---$ & OK & 0.424 & 0.152 & 2.786 & 0.005 & Significant \\
\hline
\end{tabular}

Source: Primary Data, 2017.

Structural Equation 1:

$$
Y=-0.144 X_{1}+0.511 X_{2}+0.110 X_{3}+0.376 X_{4}+e 1
$$

Where: $Y$ - Entrepreneurial Orientation, $X_{1}$ - Role of Public Policy, $X_{2}$ - Individual Characteristics, $\mathrm{X}_{3}-$ Family, $\mathrm{X}_{4}-$ Training.

Table 4 - Direct and Indirect Influence Matrix

\begin{tabular}{|c|c|c|c|c|c|c|c|}
\hline \multirow{2}{*}{ Variable } & \multirow{2}{*}{ P.L } & \multicolumn{4}{|c|}{ P.T.L } & \multirow[b]{2}{*}{ TPTL } & \multirow[b]{2}{*}{ TP } \\
\hline & & $\mathrm{Y}_{1}$ & $Y_{2}$ & $\mathrm{Y}_{3}$ & $Y_{4}$ & & \\
\hline $\mathrm{X}_{1}$ & -0.227 & -0.009 & 0.100 & 0.148 & 0.104 & -0.00001 & -0.22701 \\
\hline $\mathrm{X}_{2}$ & 0.398 & 0.468 & 0.556 & 0.442 & 0.417 & 0.0480 & 0.4460 \\
\hline$X_{3}$ & 0.191 & 0.447 & 0.437 & 0.361 & 0.339 & 0.0239 & 0.2149 \\
\hline$X_{4}$ & 0.268 & 0.106 & 0.139 & 0.228 & 0.254 & 0.0009 & 0.2689 \\
\hline & & & $R^{2} X Y$ & & & & 0.703 \\
\hline
\end{tabular}

Source: Findings of the study, 2017.

Note: PL - Direct Influence, PTL - Indirect Influence, TPTL - Total Indirect Influence, TP - Total Influence.

Structural Equation 2:

$$
Z=0.424 Y+e 2
$$

Where: $Z=$ Entrepreneurial Performance; $Y=$ Entrepreneurial Orientation.

Table 5 showed a matrix describing the direct and indirect influence.

\begin{tabular}{|c|c|c|c|c|c|c|c|c|}
\hline \multirow{2}{*}{ Variable } & \multirow{2}{*}{ P.L } & \multicolumn{4}{|c|}{ P.T.L } & & \multirow{2}{*}{ TPTL } & \multirow{2}{*}{ TP } \\
\hline & & $Z_{1}$ & $Z_{2}$ & $Z_{3}$ & $Z_{4}$ & $Z_{5}$ & & \\
\hline$Y_{1}$ & 0.145 & 0.269 & 0.193 & 0.093 & 0.107 & 0.083 & 0.0000429 & 0.1450429 \\
\hline $\mathrm{Y}_{2}$ & 0.143 & 0.196 & 0.231 & 0.219 & 0.192 & 0.111 & 0.0002113 & 0.1432113 \\
\hline $\mathrm{Y}_{3}$ & 0.163 & 0.282 & 0.313 & 0.244 & 0.328 & 0.236 & 0.0016671 & 0.1646671 \\
\hline $\mathrm{Y}_{4}$ & 0.305 & 0.280 & 0.379 & 0.314 & 0.315 & 0.306 & 0.0032119 & 0.3082119 \\
\hline \multicolumn{8}{|c|}{$\mathrm{R}^{2} \mathrm{XY}$} & 0.761 \\
\hline
\end{tabular}

Table 5 - Direct and Indirect Influence Matrix

Source: Findings of the study, 2017.

The table above showed that $\mathrm{R}^{2}$ of the influence of Public Policy and Individual Characteristics towards Entrepreneurial Orientation, Family towards Entrepreneurial Orientation, and training towards terhadap Entrepreneurial Orientation was 0.703 . Based on Chin (1998)'s classification, ability of the variables to explain Entrepreneurial Orientation was substantial or strong.

Governent role manifested in the form of government policy, socialization, implementation and supervision is pivotal in developing Entrepreneurial Orientation. Besides that, one should pay a close attention to push factory (government visit, product protection and justice), communication (consultant, access to information) and resources. 
Individual characteristic also had significant influence towards Entrepreneurial Orientation. It consisted of biography (managerial experience, education, number of dependence, ethnicity. Psychology and personality are two essential dimensions many researchers are interested in. Training was another variable that has significant influence towards Entrepreneurial Orientation.

Coefficient of determination which represented the influence of Entrepreneurial Orientation towards entrepreneurial performance was 0.761 or strong. It happened because entrepreneurial performance was influenced by other variables outside the model, for instance market orientation, environment, and management. Being proactive, risk-taking and locus of control were the dimensions of the entrepreneurial orientation. On the other hand, performance of the female entrepreneurs was measured based on sales growth, an increase in number of employees, customers, working capital and type of products.

\section{CONCLUSION}

Public policy, individual characteristics, environment and training have significant influence towards Entrepreneurial Orientation and Performance of female entrepreneurs in DKI Jakarta. However, family does not have significant influence towards their entrepreneurial orientation or performance. The findings are not in line with the previous studies in which family has significant influence towards entrepreneurial orientation. This is new findings in entrepreneur-based research.

Based on the findings, future study should discuss how other variables influence Entrepreneurial Orientation. In Indonesia, etnic group is an alternative dimension to discuss because the female entrepreneurs come from different background and ethnic groups.

\section{REFERENCES}

1. Brown, Terrence and Ulijn, Jan, (2004), Innovation, Entrepreneurship and Culture: The Interaction between Technology, Progress and Economic Growth. University of Illinois at Urbana-Champaign's Academy for Entrepreneurial Leadership Historical Research Reference in Entrepreneurship. Available at SSRN: https://ssrn.com/abstract=1496112

2. Harahap, E, St, (2007). Kamus besar bahasa Indonesia. Bandung: Balai Pustaka.

3. Harefa, Mandala (2008), Optimalisasi Kebijakan Penerimaan Daerah, ferdiifirdaus.blogspot.com/2014/06/kebijakan-pemerintah-terhadap-ukm.html.

4. Hoque, Z. \& James, W. (2000) Linking Balanced Scorecard Measures to Size and Market Factors: Impact on Organizational Performance. Journal of Management Accounting Research: December 2000, Vol. 12, No. 1, pp. 1-17.

5. Jung, D.I. (2001). Transformational and Transactional Leadership and their Effects on Creativity in Groups. Creativity Research Journal, 13(2), 185-195.

6. Leon J.A, Descals, F.J, Dominguez, J.F. (2007). The Psychosocial Profile Of The University Entrepreneur. Journal of Psychology in Spain, 11(1), 72-84.

7. Manihai, Roy. (2009). Konsep Lingkungan Keluarga Menurut Para Ahli. Tersedia pada http://aroxxkaluwatu.blogspot.com/2013/06/konsep-lingkungan-keluarga-menurutpara. html. (diakses tanggal 20 Juni 2013)

8. Moores, K., \& Yuen, S. (2001). Management accounting systems and organizational configuration: A life-cycle perspective. Accounting, Organizations \& Society, 26 (4/5), 351 389. doi:10.1016/S0361-3682(00)00040

9. Siagian, S. P. (2008). Manajemen Sumber Daya Manusia. Jakarta: Bumi Aksara

10. Sirec, K., \& Monic, D. (2010). How Enterpreneuurs' Personal Characteristics Affect SMES' Growth. Nase Gospodarstvo, ABI/INFORM Global.

11. Yusuf, S. (2012), Landasan Bimbingan Konseling, Penerbit Rosda, Bandung

12. Badan Pusat Statistik DKI Jakarta, (2012), https://jakarta.bps.go.id/ 